\title{
Adoption of Information Technology at LLDIKTI Region II with UTAUT Framework (Case Study : Lecturer Workload Application)
}

\section{Adopsi Teknologi Informasi Pada LLDIKTI Wilayah II Dengan Framework UTAUT (Studi Kasus : Aplikasi Beban Kerja Dosen)}

\author{
Intan Fitriana Wulandari ${ }^{1}$, Muhamad Ariandi ${ }^{2}$ \\ ${ }^{1}$ LLDIKTI Wilayah II, ${ }^{2}$ Sistem Informasi, Universitas Bina Darma, Palembang, Indonesia \\ Email:117141001P@student.binadarma.ac.id,2muhamad_ariandi@binadarma.ac.id
}

\begin{abstract}
Teknologi informasi menjadi salah satu bagian terpenting dalam suatu instansi, salah satu instansi yang memerlukan teknologi informasi yaitu Lembaga Layanan Pendidikan Tinggi (LLDikti) Wilayah II. LLDikti Wilayah II merupakan suatu instansi Pemerintah yang berada di bawah Kementerian Riset, Teknologi, dan Pendidikan Tinggi yang tugasnya memberikan pengawasan, pengendalian dan pembinaan terhadap Perguruan Tinggi Swasta yang ada dalam lingkungannya. Salah satu teknologi informasi yang telah digunakan adalah aplikasi teknologi informasi Beban Kerja Dosen (BKD), maka diperlukan suatu metode untuk melihat layanan teknologi informasi tersebut dengan menggunakan salah satu framework. Framework UTAUT dapat menunjukkan bagaimana pengaruh perbedaan dari setiap responden dalam menggunakan teknologi informasi. Lebih khusus lagi, hubungan antara persepsi suatu pemanfaatan, kemudahan penggunaan, dan niat penggunaan dapat dimoderatori oleh usia, jenis kelamin, golongan/pangakat, dan pengalaman dalam penggunan aplikasi teknologi informasi BKD. Dengan menggunakan variabel-variabel yang ada pada framework UTAUT tersebut diharapkan memberikan kualitas layanan teknologi informasi di LLDikti Wilayah II lebih jelas dan bisa diukur sejauh mana pengadopsian teknologi informasi BKD selama ini bagi dosen di lingkungannya dalam melakukan aktifitas kependidikan.
\end{abstract}

Keywords: BKD, LLDikti Wilayah II, UTAUT, Teknologi Informasi.

\section{PENDAHULUAN}

Dosen merupakan bagian terpenting dari salah satu komponen esensial dalam suatu sistem pendidikan pada perguruan tinggi. Dosen memiliki suatu peranan, fungsi, tugas, dan tanggungjawab sangat penting dalam mewujudkan mutu pendidikan nasional di setiap negara. Dalam melaksanakan hal tersebut, 
diperlukan dosen yang profesional. Teknologi informasi Beban Kerja Dosen atau yang biasa disebut Laporan BKD merupakan kegiatan tri dharma perguruan tinggi yang dilakukan oleh dosen yang telah memiliki Sertifikasi Dosen (serdos) untuk melaksanakan tanggung jawab mereka pada setiap semester yang meliputi bidang: pendidikan dan pengajaran, penelitian, pengabdian kepada masyarakat, dan penunjang kegiatan tridharma perguruan tinggi. Teknologi informasi laporan BKD tersebut dalam penerapan adopsinya belum pernah dilakukan analisis pengaruhnya bagi para pengguna. Berdasarkan hal tersebut, teknologi informasi menjadi salah satu bagian terpenting dalam suatu instansi penyelenggara pendidikan, salah satu instansi yang memerlukan teknologi informasi yaitu Lembaga Layanan Pendidikan Tinggi (LLDikti) Wilayah II.

Lembaga Layanan Pendidikan Tinggi (LLDikti) Wilayah II merupakan suatu instansi Pemerintah yang berada di bawah Kementerian Riset, Teknologi, dan Pendidikan Tinggi. LLDikti Wilayah II secara langsung mewakili Kementerian dalam menjalankan aktivitas kependidikan tinggi dimana tugasnya memberikan pengawasan, pengendalian dan pembinaan terhadap Perguruan Tinggi Swasta yang ada dalam lingkungannya, yaitu meliputi wilayah Provinsi Sumatera Selatan, Provinsi Bandar Lampung, Provinsi Bengkulu dan Provinsi Bangka Belitung. Bebrapa aktivitas yang dilakukan LLDikti seperti pengurusan Nomor Induk Dosen Nasional (NIDN), Akreditasi, penelitian dosen dan mahasiswa dan Pengabdian Dosen pada masyarakat, Jenjang Jabatan Akademik (JJA) dosen, kepangkatan, beasiswa, Sertifikasi Dosen (Serdos) dan masih banyak lagi. Selain itu, LLDikti memiliki tugas sebagai pemeriksa/verifikator laporan sertifikasi dosen yang nantinya akan diverifikasi kesesuaian berkas dengan aplikasi teknologi informasi laporan BKD yang dikumpulkan secara kolektif oleh masing-masing perguruan tinggi swasta di lingkungan LLDikti Wilayh II sebagai dasar pembayaran tunjangan sertifikasi dosen.

Dalam melakukan pemanfaatan adopsi teknologi informasi laporan BKD pada LLDikti Wilayah II selama ini belum pernah dilakukan analisis akan pengaruhnya bagi pengguna dalam melakukan aktivitasnya. Dalam menganalisis adopsi teknologi informasi tersebut, diperlukan suatu metode untuk mengukur pemanfaatan tersebut dengan menggunakan salah satu framework yaitu framework Teori Terpadu tentang Penerimaan dan Penggunaan Teknologi Unified Theory of Acceptance and Use of Technology (UTAUT) yang dikembangkan oleh Venkatesh, et al (2003). Framework UTAUT dapat menunjukkan bagaimana pengaruh perbedaan dari setiap responden dalam menggunakan teknologi informasi. Lebih khusus lagi, hubungan antara persepsi suatu pemanfaatan, kemudahan penggunaan, dan niat penggunaan dapat dimoderatori oleh usia, jenis kelamin, golongan/pangakat, dan pengalaman dalam penggunan aplikasi teknologi informasi BKD. Dengan menggunakan variabel-variabel yang ada pada framework UTAUT tersebut diharapkan 


P-ISSN: 2656-5935 http://journal-isi.org/index.php/isi e-ISSN: 2656-4882

memberikan kualitas layanan teknologi informasi di LLDikti Wilayah II lebih jelas dan bisa diukur sejauh mana pengadopsian teknologi informasi laporan BKD selama ini bagi dosen di lingkungannya dalam melakukan aktifitas kependidikan. Penelitian dengan metode yang sama sebelumnya sudah dilakukan dalam Evaluasi Dampak Aplikasi Human Resource of Information System (HRIS) terhadap Peningkatan Aktivitas Pengurus Jenjang Akademik Dosen dengan Motode UTAUT (Ariandi. M, 2014).

Dari uraian tersebut, maka peneliti berkeinginan untuk melakukan analisa terhadap faktor keberhasilan dalam pengadopsian teknologi informasi Laporan Beban Kerja Dosen (BKD) pada Lembaga Layanan Pendidika Tinggi Wilayah II dengan menggunakan model pendekatan atau framework UTAUT, diharapkan hasil yang diinginkan bisa lebih baik dan tepat untuk para penggunanya dan pihak terkait, seperti Perguruan Tinggi, LLDikti dan Lembaga Pemerintahan lainnya.

\section{METODE PENELITIAN}

Penelitian ini memiliki beberapa ratusan dari subjek pada populasi yang ada, dimana kita dapat menentukan jumlah tersebut $\pm 25 \%-30 \%$ pada jumlah subjek. Jika total anggota subjek pada populasi hanya meliputi nilai 100-150 orang dan dalam pengumpulan data penelitian menggunakan data angket/kuisoner, sebaiknya subjek harus sejumlah data yang diambil seluruhnya. Sehingga dapat dikatakan sebagai suatu penelitian sensus.

\subsection{Objek Penelitian}

Dalam penelitian ini yang menjadi objek kajian adalah Aplikasi Beban Kinerja Dosen (BKD). Laporan Beban Kerja Dosen (BKD) adalah Kegiatan pelaksanaan tri dharma perguruan tinggi yang dilakukan oleh dosen yang meliputi bidang: Pendidikan dan Pengajaran, Penelitian, Pengabdian kepada Masyarakat, dan Penunjang Kegiatan Tridharma Perguruan Tinggi. Aplikasi ini digunakan untuk pelaporan BKD pada tiap semesternya sebagai dasar pencairan dana tunjangan sertifikasi dosen.

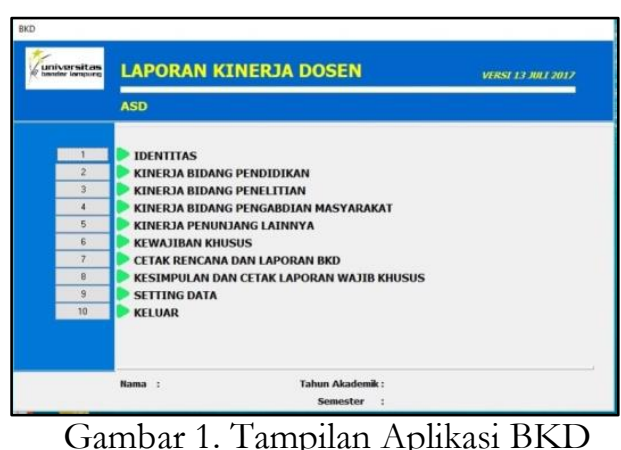


Dalam penerapannya, ruang lingkup BKD meliputi:

a. Merencanakan dan melaksanakan proses pembelajaran

b. Melakukan evaluasi pembelajaran

c. Membimbing, melatih dan menguji mahasiswa

d. Melakukan penelitian dan pengabdian pada masyarakat

e. Melakukan tugas tambahan dan atau unsur penunjang

\subsection{Populasi dan Sampel}

Sampel merupakan bagian dari populasi yang mewakili untuk diteliti. Sampel penelitian sendiri merupakan sebagian dari populasi yang diambil sebagai sumber data dan dapat mewakili dari seluruh populasi. Jika penelitian mempunyai beberapa ratusan subjek dalam populasi, mereka dapat menentukan kurang lebih 25\%-30\% dari jumlah subjek tersebut, dan hanya meliputi antara 100-150 orang dalam pengumpulan data penelitian menggunakan angket/kuisioner, sebaiknya subjek sejumlah itu diambil seluruhnya. Sehingga dapat dikatakan sebagai penelitian sensus (Sugiyono, 2010). Mengenai sensus, menurut Ruslan (2008) bahwa sensus dilakukan dengan alasan penelitian sebaiknya harus mempertimbangkan data untuk meneliti seluruh elemen-elemen dari populasi, jika elemen populasi relatif sedikit dan variabilitas setiap elemennya yang tinggi (heterogen), maka sebaiknya sensus lebih layak dilakukan jika penelitian yang dimaksudkan untuk menjelaskan karakteristik setiap elemen dari suatu populasi.

$$
\mathrm{n}=\frac{\mathrm{N}}{\mathrm{Nd}^{2}+1}
$$

$\mathrm{n}=$ ukuran sampel

$\mathrm{N}=$ Ukuran populasi

$\mathrm{d}^{2}=$ Batas toleransi kesalahan pengambilan sampel yang digunakan (5\%)

$$
\text { Dosen : } \quad \begin{aligned}
n & =\frac{2547}{2547 \cdot(0.05)^{2}+1}=\frac{2547}{2547 \cdot(0.0025)+1} \\
\mathrm{n} & =\frac{2547}{6,367+1} \\
\mathrm{n} & =\frac{2547}{7,367} \\
\mathrm{n} & =345,7 \text { dibulatkan menjadi } 346
\end{aligned}
$$

Tabel 1. Sebaran Populasi Dosen Bersertifikasi

\begin{tabular}{clcc}
\hline No & & PT LLDikti Wilayah II & Jumlah \\
\hline 1 & Palembang & & 1462 \\
2 & Lampung & & 670 \\
3 & Bengkulu & & 383 \\
4 & Bangka Belitung & 32 \\
\hline \multicolumn{2}{c}{} & Jumlah & $\mathbf{2 5 4 7}$ \\
\hline
\end{tabular}

Sumber : LLDikti Wilayah II (Maret 2019) 


P-ISSN: 2656-5935 http://journal-isi.org/index.php/isi e-ISSN: 2656-4882

\section{HASIL DAN PEMBAHASAN}

Pada desain penelitian ini telah menjelaskan bahwa responden merupakan dosen yang telah disertifikasi di lingkungan LLDikti Wilayah II, dimana dalam menyelesaikan pelaporan Beban Kerja Dosen (BKD) tentunya menggunakan Aplikasi BKD. Dari hasil penelitian terdapat 616 orang pengguna Aplikasi BKD dalam mengisi angket kuisioner yang disebarkan melalui form google dalam memasukan data, sehingga data yang mampu diolah dalam pengolahan data berjumlah 616 orang.

Model UTAUT adalah suatu model penerimaan teknologi informasi yang digunakan serta dikembangkan berdasarkan teori dan model dari sebelumnya. Model ini digunakan untuk menguji faktor-faktor penentu user acceptance dan perilaku terhadap pengguna yang terdiri dari: performance expectancy, effort expectancy, social influence dan facilitating conditions, dan menemukan bahwa keempat hal tersebut saling berhubungan terhadap pengguna baik secara langsung maupun tidak langsung dari variabel behavioral intention. UTAUT juga dapat melihat pengaruh yang dilakukan, seperti usia, jenis kelamin, karakteristik jabatan fungsional, karakteristik pangkat/golongan, dan pengalaman si pengguna dalam menggunakan Aplikasi BKD tersebut.

Tabel 2. Karaterestik Usia Responden

\begin{tabular}{|ll|r|r|r|r|}
\hline & Frequency & Percent & $\begin{array}{c}\text { Valid } \\
\text { Percent }\end{array}$ & $\begin{array}{c}\text { Cumulative } \\
\text { Percent }\end{array}$ \\
\hline Valid & 25 - 35 Tahun & 227 & 36,9 & 36,9 & 36,9 \\
36- 45 Tahun & 205 & 33,3 & 33,3 & 70,1 \\
46-55 Tahun & 134 & 21,8 & 21,8 & 91,9 \\
56-65 Tahun & 49 & 8,0 & 8,0 & 99,8 \\
66- 70 Tahun & 1 &, 2 &, 2 & 100,0 \\
Total & 616 & 100,0 & 100,0 & \\
\hline
\end{tabular}

Data yang diperoleh dalam pengolahan data, diketahui bahwa hasil dari jumlah total yang didapat adalah 616 responden, terdiri dari 227 orang atau 36,9\% dengan rata-rata golongan umur 25-35 tahun, 205 orang atau 33,3\% dengan ratarata golongan umur 36-45 tahun, 134 orang atau 21,8\% dengan rata-rata golongan umur 46-55 tahun, terdapat 49 orang atau $8 \%$ dengan rata-rata golongan umur 56-65 tahun, terdapat 1 orang atau $0,2 \%$ dengan rata-rata golongan umur 66-70 tahun. Berdasarkan data pada kalimat sebelumnya, maka dapat disimpulkan mayoritas golongan umur adalah 25-35 tahun. 
Journal of Information Systems and Informatics

Vol. 1, No. 2, September 2019

p-ISSN: 2656-5935 http://journal-isi.org/index.php/isi e-ISSN: 2656-4882

Tabel 3. Karaterestik Jenis Kelamin Responden

\begin{tabular}{|ll|r|r|r|r|}
\hline & Frequency & Percent & Valid Percent & $\begin{array}{c}\text { Cumulative } \\
\text { Percent }\end{array}$ \\
\hline Valid & Laki - Laki & 244 & 39,6 & 39,6 & 39,6 \\
& Perempuan & 372 & 60,4 & 60,4 & 100,0 \\
& Total & 616 & 100,0 & 100,0 & \\
\hline
\end{tabular}

Data yang diperoleh berdasarkan jenis kelamin memiliki dengan total 616 responden, terdapat 244 orang atau 39,6\% responden berjenis kelamin laki-laki dan 372 orang atau $60,4 \%$ responden berjenis kelamin perempuan. Sehingga dapat disimpulkan bahwa mayoritas responden adalah berjenis kelamin perempuan.

Tabel 4. Karaterestik Jabatan Fungsional Responden

\begin{tabular}{|c|c|c|c|c|c|}
\hline & & Frequency & Percent & Valid Percent & $\begin{array}{c}\text { Cumulative } \\
\text { Percent }\end{array}$ \\
\hline \multirow[t]{5}{*}{ Valid } & Asisten Ahli & 288 & 46,8 & 46,8 & 46,8 \\
\hline & Guru Besar & 5 & 8 & ,8 & 47,6 \\
\hline & Lektor & 269 & 43,7 & 43,7 & 91,2 \\
\hline & Lektor Kepala & 54 & 8,8 & 8,8 & 100,0 \\
\hline & Total & 616 & 100,0 & 100,0 & \\
\hline
\end{tabular}

Dari data yang diperoleh berdasarkan Jabatan Fungsional responden, diketahui bahwa dari total 616 responden, terdapat 288 atau 246,8\% responden dengan jabatan Asisten Ahli, terdapat 5 atau 0,8\% responden dengan jabatan Guru Besar, terdapat 269 atau 43,7\% responden dengan jabatan Lektor, dan terdapat 54 atau 8,8\% responden dengan jabatan Lektor Kepala. Maka dapat disimpulkan mayoritas responden adalah dosen dengan jabatan fungsional Lektor.

Tabel 5. Karaterestik Pangkat/Golongan Responden

\begin{tabular}{|l|r|r|r|r|}
\hline & Frequency & Percent & $\begin{array}{c}\text { Valid } \\
\text { Percent }\end{array}$ & $\begin{array}{c}\text { Cumulative } \\
\text { Percent }\end{array}$ \\
\hline V III/a, Penata Muda & 36 & 5,8 & 5,8 & 5,8 \\
a III/b, Penata Muda TK.I & 302 & 49,0 & 49,0 & 54,9 \\
l III/c, Penata & 172 & 27,9 & 27,9 & 82,8 \\
i III/d, Penata TK.1 & 52 & 8,4 & 8,4 & 91,2 \\
d IV/a, Pembina & 24 & 3,9 & 3,9 & 95,1 \\
IV/b, Pembina TK.I & 12 & 1,9 & 1,9 & 97,1 \\
IV/c, Pembina Utama Muda & 15 & 2,4 & 2,4 & 99,5 \\
IV/d, Pembina Utama Madya & 1 &, 2 &, 2 & 99,7
\end{tabular}




p-ISSN: 2656-5935 http://journal-isi.org/index.php/isi e-ISSN: 2656-4882

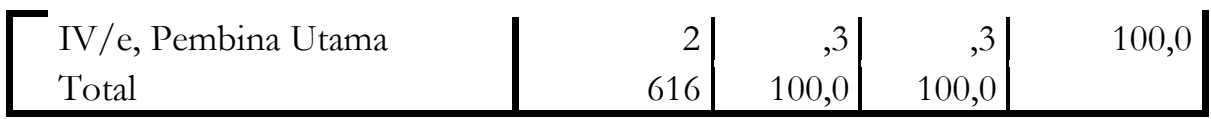

Data yang diperoleh berdasarkan pangkat/golongan responden, dapat diketahui bahwa dari jumlah total 616 responden, terdapat 36 atau 5,8\% responden dengan pangkat (III/a, Penata Muda), terdapat 302 atau $49 \%$ responden dengan pangkat (III/b, Penata Muda TK.I), terdapat 172 atau 27,9\% responden dengan pangkat (III/c, Penata), terdapat 52 atau $8,4 \%$ responden dengan pangkat (III/d, Penata TK.1), terdapat 24 atau 3,9\% responden dengan pangkat (IV/a, Pembina), terdapat 12 atau 1,9\% responden dengan pangkat (IV/b, Pembina TK.I), terdapat 15 atau $2,4 \%$ responden dengan pangkat (IV/c, Pembina Utama Muda), terdapat 1 atau $0,2 \%$ responden dengan pangkat (IV/d, Pembina Utama Madya), dan 2 atau 0,3\% responden dengan pangkat (IV/e, Pembina Utama). Maka dapat disimpulkan mayoritas responden adalah dosen dengan pangkat (III/b, Penata Muda TK.I).

Tabel 6. Karaterestik Lama Menggunakan Aplikasi BKD

\begin{tabular}{|c|c|c|c|c|c|}
\hline & & Frequency & Percent & Valid Percent & $\begin{array}{c}\text { Cumulative } \\
\text { Percent }\end{array}$ \\
\hline \multirow[t]{4}{*}{ Valid } & 1-3 Tahun & 388 & 63,0 & 63,0 & 63,0 \\
\hline & 4- 6 Tahun & 127 & 20,6 & 20,6 & 83,6 \\
\hline & 7 - 9 Tahun & 101 & 16,4 & 16,4 & 100,0 \\
\hline & Total & 616 & 100,0 & 100,0 & \\
\hline
\end{tabular}

Data yang diperoleh berdasarkan lama menggunakan Aplikasi BKD responden, memiliki total 616 responden, terdapat 388 atau $63 \%$ responden telah menggunaan Aplikasi BKD selama 1-3 tahun, terdapat 127 atau 20,6\% responden telah menggunaan Aplikasi BKD selama 4-6 tahun dan terdapat 101 atau 16,4\% responden telah menggunaan Aplikasi BKD selama 7-9 tahun. Maka dapat disimpulkan mayoritas responden yang telah menggunaan Aplikasi BKD adalah 1-3 tahun.

\subsection{Uji Validitas}

Uji validilitas digunakan untuk mengetahui kevalidan angket dalam mengumpulkan data hasil kuisioner. Perhitungan uji validitas menggunakan rumus korelasi Bivariate person dengan alat bantu program SPSS versi 23. Item angket dalam uji validitas dikatakan valid jika harga $\mathrm{r}_{\text {hitung }}>\mathrm{r}_{\text {tabel }}$ pada nilai signifikan 5\%, sebaiknya item dikatakan tidak valid jika harga $\mathrm{r}_{\text {hitung }}>\mathrm{r}_{\text {tabel }}$ pada nilai signifikan 5\%. Berdasarkan $\mathrm{r}_{\text {tabel }}$ yang dilakukan pada tabel uji validitas untuk 616 responden adalah 0,079 . 
Journal of Information Systems and Informatics

Vol. 1, No. 2, September 2019

p-ISSN: 2656-5935 http://journal-isi.org/index.php/isi e-ISSN: 2656-4882

Tabel 7. Variable Performance Expectancy (Ekspetasi Kerja)

\begin{tabular}{|c|c|c|c|}
\hline No Item & Rxy & R Tabel 5\% & Keterangan \\
\hline X1_1 & 0,882 & 0,079 & Valid \\
X1_2 & 0,866 & 0,079 & Valid \\
X1_3 & 0,856 & 0,079 & Valid \\
X1_4 & 0,858 & 0,079 & Valid \\
X1_5 & 0,836 & 0,079 & Valid \\
X1_6 & 0,843 & 0,079 & Valid \\
X1_7 & 0,865 & 0,079 & Valid \\
\hline
\end{tabular}

Berdasarkan hasil uji validitas dapat diketahui semua nilai $\mathrm{r}_{\text {hitung }}>\mathrm{r}_{\text {tabel }}$ dengan nilai signifikasi 5\% dapat dinyatakan valid. Sehingga bisa disimpulkan bahwa semua item variabel performance expectancy pada semua indikator valid dan bisa dipakai untuk alat bantu penelitian.

Tabel 8. Variable Effort Expectancy (Ekspetasi Usaha)

\begin{tabular}{|c|c|c|c|}
\hline No Item & Rxy & R tabel 5\% & Keterangan \\
\hline X2_1 & 0,841 & 0,079 & Valid \\
X2_2 & 0,882 & 0,079 & Valid \\
X2_3 & 0,885 & 0,079 & Valid \\
X2_4 & 0,915 & 0,079 & Valid \\
\hline
\end{tabular}

Pada semua item indikator variabel effort expectancy, hasil perhitungan yang didapat, bahwa semua nilai $r_{\text {hitung }}>r_{\text {tabel }}$ pada nilai signifikasi $5 \%$ untuk uji validitas. Sehingga bisa disimpulkan semua item variabel effort expectancy pada semua indikatornya dinyatakan valid dan dapat menjadi alat bantu penelitian.

Tabe1 9. Variable Social Influence (Pengaruh Sosial)

\begin{tabular}{|c|c|c|c|}
\hline No Item & Rxy & R tabel 5\% & Keterangan \\
\hline X3_1 & 0,823 & 0,079 & Valid \\
X3_2 & 0,822 & 0,079 & Valid \\
X3_3 & 0,888 & 0,079 & Valid \\
X3_4 & 0,886 & 0,079 & Valid \\
\hline
\end{tabular}

Hasil perhitungan untuk uji validitas dari nilai $\mathrm{r}_{\text {hitung }}>\mathrm{r}_{\text {tabel }}$ pada nilai signifikasi $5 \%$ dapat dinyatakan valid. Sehingga dapat disimpulkan semua butir-butir item dalam variabel social influence pada angket penelitian ini valid dan bisa digunakan sebagai alat bantu penelitian.

Tabel 10. Variable Facilitating Condition (Memfasilitasi Kondisi)

\begin{tabular}{|c|c|c|c|}
\hline No Item & Rxy & R tabel 5\% & Keterangan \\
\hline X4_1 & 0,805 & 0,079 & Valid \\
X4_2 & 0,792 & 0,079 & Valid \\
\hline
\end{tabular}


Vol. 1, No. 2, September 2019

\begin{tabular}{|c|c|c|c|}
\hline p-ISSN: $2656-5935$ & \multicolumn{2}{|c|}{ http://journal-isi.org/index.php/isi } & e-ISSN: $2656-4882$ \\
\hline X4_3 & 0,705 & 0,079 & Valid \\
\hline $\mathrm{X} 4 \_4$ & 0,750 & 0,079 & Valid \\
\hline
\end{tabular}

Hasil perhitngan uji validitas menunjukkan bahwa semua nilai $r_{\text {hitung }}>r_{\text {tabel }}$ pada variabel facilitating condition dalam penelitian ini dinyatakan valid dan bisa dipakai untuk alat bantu penelitian.

Tabel 11. Variable Behavioral Intention (Niat Perilaku)

\begin{tabular}{|c|c|c|c|}
\hline No Item & Rxy & R tabel 5\% & Keterangan \\
\hline Y1_1 & 0,919 & 0,079 & Valid \\
Y1_2 & 0,912 & 0,079 & Valid \\
Y1_3 & 0,904 & 0,079 & Valid \\
\hline
\end{tabular}

Berdasarkan hasil dari uji validitas diatas, dapat dilihat semua harga $r_{\text {hitung }}>r_{\text {tabel }}$ pada nilai signifikasi 5\%. Sehingga bisa disimpulkan untuk semua item variabel behavioral intention dalam penelitian ini valid dan bisa dipakai untuk alat bantu penelitian.

Tabel 12. Variable Use Behavior (Perilaku)

\begin{tabular}{|c|c|c|c|}
\hline No Item & Rxy & R tabel 5\% & Keterangan \\
\hline Z1_1 & 0,883 & 0,079 & Valid \\
Z1_2 & 0,924 & 0,079 & Valid \\
Z1_3 & 0,883 & 0,079 & Valid \\
\hline
\end{tabular}

Hasil dari uji validitas menghasilkan semua harga $r_{\text {hitung }}>r_{\text {tabel }}$ pada nilai signifikasi $5 \%$. Sehingga bisa disimpulkan semua item variabel use behavior dalam penelitian ini valid dan bisa digunakan dalam penelitian.

\subsection{Uji Reabilitas}

Uji reliabilitas dilakukan untuk menguji seberapa koefisien perangkat instrument pengukuran dalam perhitungan secara konsisten terhadap konsep studi kasus yang digunakan untuk mengukur perangkat agar tetap menunjukkan kestabilan. Pengujian ini menggunakan koefisien cronbach's alpha. Rules of thumb menunjukkan bahwa nilai cronbach's alpha harus lebih besar $(>)$ atau sama( $(=)$ dengan 0,6 (Cornelius Trihendradi, 2012). Uji reliabilitas ini menggunakan rumus alpha $(\alpha)$, dimana uji signifikan pada taraf $\alpha=0,05$. Instrumen bisa dikatakan reliabel jika nilai alpha lebih besar dari rtabel $(0,079)$ dan nilai cronbach alpa $>0,6$. 
Vol. 1, No. 2, September 2019

p-ISSN: 2656-5935 http://journal-isi.org/index.php/isi $\quad$ e-ISSN: 2656-4882

Tabel 13. Hasil Uji Reliabilitas

\begin{tabular}{|l|c|c|c|}
\hline \multicolumn{1}{|c|}{ Variabel } & Rxy & Cronbach Alpha & Keterangan \\
\hline Performance Expectancy & 0,940 & 0,6 & Reliable \\
Effort Expectancy & 0,904 & 0,6 & Reliable \\
Sosial Influence & 0,893 & 0,6 & Reliable \\
Facilitating Conditions & 0,751 & 0,6 & Reliable \\
Behavioral Intention & 0,898 & 0,6 & Reliable \\
Use Behavior & 0,878 & 0,6 & Reliable \\
\hline
\end{tabular}

Berdasarkan nilai koefisien reliabilitas yang dilakukan pada perhitungan diatas, dapat disimpulkan bahwa semua angket dalam penelitian ini reliable atau konsisten.

Hasil dari penelitian menunjukkan kondisi responden dalam memberikan tanggapan pada kuisioner yang diberikan, yang jika dimasukkan dalam rentang nilai kategori skor, rata-rata skor tersebut dapat dikategorikan sebagai berikut:

$$
\begin{array}{lr}
\begin{array}{lr}
\text { Skor minimal } \\
\text { Skor maksimal }
\end{array} & =1 \\
& =5 \\
\hline \text { Rentang sK } & =\frac{5-1}{4}=1
\end{array}
$$

Rentang kategori skor diperoleh sebagai berikut :

\begin{tabular}{|c|c|}
\hline Skor & Keterangan \\
\hline $1.00-2.00$ & Sangat Buruk \\
\hline $2.01-3.00$ & Buruk \\
\hline $3.01-4.00$ & Sedang \\
\hline $4.01-5.00$ & Baik \\
\hline
\end{tabular}

Berikut ini adalah pembahasan hasil statistik deskriptif terhadap rekapitulasi kuisioner.

Tabel 14. Statistik Deskriptif

\begin{tabular}{|l|c|c|c|c|c|}
\hline $\begin{array}{c}\text { Observed } \\
\text { Variables }\end{array}$ & Minimum & Maximum & Mean & $\begin{array}{c}\text { Std. } \\
\text { Deviation }\end{array}$ & Keterangan \\
\hline \multicolumn{5}{|c|}{ Performance Expectancy (X1) } \\
\hline Perceived Usefulness \\
\hline PE1 & 2 & 4 & 4,28 & 0,758 & Baik \\
\hline PE2 & 1 & 4 & 4,27 & 0,785 & Baik \\
\hline Extrinsic Motivation \\
\hline PE3 & 4 & 4,17 & 0,753 & Baik \\
\hline Job Fit & 1 & 4 & 4,26 & 0,787 & Baik \\
\hline PE4 & 1 &
\end{tabular}


Vol. 1, No. 2, September 2019

\begin{tabular}{|c|c|c|c|c|c|}
\hline $\begin{array}{l}\text { Observed } \\
\text { Variables }\end{array}$ & Minimum & Maximum & Mean & $\begin{array}{c}\text { Std. } \\
\text { Deviation }\end{array}$ & Keterangan \\
\hline \multicolumn{6}{|c|}{ Relative Advantage } \\
\hline PE5 & 1 & 4 & 4,06 & 0,799 & Baik \\
\hline \multicolumn{6}{|c|}{ Outcome Expectations } \\
\hline PE6 & 1 & 4 & 4,16 & 0,774 & Baik \\
\hline PE7 & 1 & 4 & 4,10 & 0,763 & Baik \\
\hline \multicolumn{6}{|c|}{ Effort Expectancy (X2) } \\
\hline \multicolumn{6}{|c|}{ Perceived Ease of Use } \\
\hline EE1 & 1 & 4 & 4,15 & 0,718 & Baik \\
\hline EE2 & 1 & 4 & 4,07 & 0,755 & Baik \\
\hline \multicolumn{6}{|c|}{ Complexity } \\
\hline EE3 & 1 & 4 & 3,95 & 0,807 & Sedang \\
\hline \multicolumn{6}{|c|}{ Ease of Use } \\
\hline EE4 & 1 & 4 & 4,06 & 0,796 & Baik \\
\hline \multicolumn{6}{|c|}{ Social Influence (X3) } \\
\hline \multicolumn{6}{|c|}{ Subjective Norm } \\
\hline SI1 & 1 & 4 & 4,21 & 0,748 & Baik \\
\hline \multicolumn{6}{|c|}{ Social Factors } \\
\hline SI2 & 1 & 4 & 3,91 & 0,809 & Sedang \\
\hline \multicolumn{6}{|c|}{ Image } \\
\hline SI3 & 1 & 4 & 3,92 & 0,814 & Sedang \\
\hline SI4 & 1 & 4 & 4,09 & 0,777 & Baik \\
\hline \multicolumn{6}{|c|}{ Facilitating Conditions (X4) } \\
\hline \multicolumn{6}{|c|}{ Perceived Behavioral Control } \\
\hline FC1 & 1 & 4 & 3,95 & 0,759 & Sedang \\
\hline FC2 & 1 & 4 & 3,99 & 0,760 & Sedang \\
\hline \multicolumn{6}{|c|}{ Facilitating Conditions } \\
\hline FC3 & 1 & 4 & 3,80 & 0,904 & Sedang \\
\hline \multicolumn{6}{|c|}{ Compatibility } \\
\hline FC4 & 1 & 4 & 3,61 & 0,913 & Sedang \\
\hline \multicolumn{6}{|c|}{ Behavioral Intentions (Y) } \\
\hline BI1 & 2 & 4 & 4,08 & 0,756 & Baik \\
\hline BI2 & 1 & 4 & 4,07 & 0,759 & Baik \\
\hline BI3 & 2 & 4 & 4,22 & 0,735 & Baik \\
\hline UB1 & 2 & 4 & 4,16 & 0,765 & Baik \\
\hline UB2 & 1 & 4 & 4,08 & 0,805 & Baik \\
\hline UB3 & 2 & 4 & 4,02 & 0,767 & Baik \\
\hline
\end{tabular}

Statistik deskriptif untuk masing-masing variabel yang didasarkan pada jawaban responden mengenai keempat variabel penelitian menunjukkan penilaian yang baik. Dari hasil tabel statistik deskriptif, maka dengan seluruh observed variables di 


p-ISSN: 2656-5935 http://journal-isi.org/index.php/isi e-ISSN: 2656-4882

atas, di dapat nilai maximum dan minimum dari beberapa rentang kategori yang diperoleh berdasarkan penilaian butir pertanyaan dari X1 sampai X4, dimana skor 1 memiliki keterangan 1.00-2.00 memiliki keterangan sangat buruk, skor 2.01-3.00 memiliki keterangan buruk, skor 3.01-4.00 memiliki keterangan sedang dan skor 4.01 sampai 5.00 memiliki katerangan baik. Serta didapat nilai rata-rata (mean) dan nilai standart deviation, sehingga dapat disimpulkan hasil perhitungan. Jika keterangan hasilnya baik maka sistem tersebut dinyatakan dapat diterima oleh user, apabila keterangan dari tabel statistik deskriptif sedang maka sistem tersebut bisa diterima atau tidak dan jika keterangan hasilnya buruk maka sistem tersebut tidak dapat diterima oleh user, sehingga sistem tersebut harus ditingkatkan lebih baik lagi.

\section{KESIMPULAN}

Adapun kesimpulan dari Analisis Perilaku Pengguna Terhadap Adopsi Teknologi Informasi Laporan Beban Kerja Dosen Pada LLDikti Wilayah II Dengan Penerapan Framework UTAUT yaitu :

1) Indikator pada variabel performance expectancy (X1) didapatkan bahwa data hasil uji validitas variabel dan indikator dinyatakan valid, sehingga dapat digunakan pengguna (user), serta sangat berpengaruh terhadap Behavioral Intention.

2) Variabel effort expectancy dengan dimensi complexity dan ease of use didapatkan bahwa dari olah data uji validitas terhadap variabel dan indikator tersebut dinyatakan valid, mampu digunakan pengguna (user) serta sangat berpengaruh terhadap Behavioral Intention.

3) Pada variabel facilitating conditions dimensi facilitating conditions dan outcome expectations disimpulkan bahwa dari olah uji validitas dinyatakan valid, dan bisa diterima oleh pengguna (user). Serta sangat berpengaruh terhadap variabel Behavioral Intention.

4) Untuk keseluruhan dimensi dan variabel social influence, bahwa hasil olah uji validitas dinyatakan memiliki nilai valid dan bisa digunakan oleh pengguna (user). Serta sangat berpengaruh terhadap variabel use behavioral intention.

\section{DAFTAR PUSTAKA}

[1] Ariandi, M. (2014). Evaluasi Dampak Aplikasi Human Resource of Information System (HRIS) Terhadap Peningkatan Aktivitas Pengurus Jenjang Akademik Dosen Dengan Metode Unified Theory of Acceptance and Use of Technology (UTAUT). Semnas Teknomedia . ISSN 2302-3805, pp. 3.05-65 - 3.05-70. Yogyakarta: Open Jurnal System Amikom.

[2] Cornelius, T. (2012). Step By Step SPSS 20 Analisis Data Statistik. Yogyakarta: Andi.

[4] Sugiyono. (2010). Metode Penelitian Bisnis. Alfabeta. 
Journal of Information Systems and Informatics

Vol. 1, No. 2, September 2019

p-ISSN: 2656-5935 http://journal-isi.org/index.php/isi e-ISSN: 2656-4882

[5] Venkatesh, M. D. (2003). User Acceptance Of Information Technology : Toward A Unified View. MIS Quarterly, 1-54. 